NGTT Deel 54, Nommers 3 \& 4, September en Desember 2013

Meiring, PGJ (Piet) ${ }^{1}$

University of Pretoria

\title{
Ukubuyisa and Ukuhlanza: Reconciliation and the Washing of the Spears. The role of the faith communities in the quest for healing and reconciliation
}

\begin{abstract}
Taking his cue from the two Zulu words Ukubuyisa (to reconcile with the dead) and Ukuhlanza (the washing of the spears), the author discusses the role that the South African faith communities may play in the quest for healing and reconciliation. A number of prerequisites for reconciliation and peace-building exist, and must be addressed by the Christian churches as well as by the other faith communities in the country. Inviting the reader to page with him through the picture book of reconciliation, the author discusses some of these prerequisites, as well as the way in which different role players within the Christian, African Traditional, Hindu and Muslim communities, have attempted to deal with them in the recent past in South Africa.
\end{abstract}

\section{RECONCILIATION IN THE ZULU TRADITION}

Much has been said, and written, on the subject of reconciliation in South Africa in recent times. Since the appointment of the South African Truth and Reconciliation Commission (TRC) seventeen years ago (1995), the issue of national healing has been on the agenda of virtually all South Africans, government, political parties, faith communities, non-governmental organisations, the media, academic institutions as well as the business community. It is therefore fitting that at the reopening and rededication of the Voortrekker Church and Museum in Pietermaritzburg (April 22, 2012), the need for healing and reconciliation should be on the table, once again. But what does reconciliation in South Africa at large - and especially between the Zulu people, Afrikaners and English in the narrower context of Kwazulu-Natal - entail? What are the prerequisites for forgiveness and healing? In this article, based on an address delivered at the ceremony in Pietermaritzburg, some answers to these questions are offered.

I would like to start my quest for answers by remembering two Zulu words: ukubuyisa and ukuhlanza. Two colleagues of mine, one a university professor in Pretoria, the other a pastor in a rural congregation in Kwazulu-Natal, acted as my teachers, helping me to understand the two concepts. Here is what I have learned from Professor Maake Masango from the Faculty of Theology, University of Pretoria, and from the Reverent Simon Kwesaba from the KwaDukuza Congregation (Uniting Reformed Church of Southern Africa), Stanger, Kwazulu-Natal. ${ }^{2}$

Imagine yourself in a Zulu village a hundred and fifty years ago, they said. Unrest is in the air. The villagers are anxiously awaiting the return of the warriors. A week earlier the chief and the

1 Piet Meiring is an emeritus professor at the Faculty of Theology, University of Pretoria. He served on the

South African Truth and Reconciliation Commission (1996-1998).

2 The interviews with Professor Masango and Reverent Kwesaba took place during April, 2012. 
NGTT: Oopbron - http://ngtt.journals.ac.za

medicine man, the inyanga, sent them away to confront the enemy. "Stand up to the enemy", the chief said to them. "Be brave. The lives of your wives and children are at stake. Kill those who want to kill us!" The medicine man, after sprinkling water and muti on the young men, called upon the ancestors to protect them in battle.

And now the warriors are back, victorious, shouting and singing. But, strangely, the chief does not invite them back into the village. They have to sleep outside the wooden fence. They have blood on their hands and on their spears. They are ritually unclean. They are not allowed into the community before they have calmed down, before peace has been restored. The dead, those who had been killed in battle, had to be buried. That is what ukubuyisa is about: to restore peace, to reconcile with the dead, to come to term 1 with the anguish and the pain of the bereaved. But a second ceremony is needed as well: ukuhlanza, the washing of the spears. The inyanga accompanies the warriors to water, where the blooded spears, the assegais, have to be cleansed. The meaning is evident: The young men's hearts and minds need cleansing. Their aggression has to be washed away. Peace must be restored before their wives and children may embrace them. Ukubuyisana is the call to the young warriors to return to one another, the living and the dead, and to come back to one another.

\section{THE UNIVERSAL CRY FOR RECONCILIATION}

To return to one another, is the universal plea that is raised in many communities in our world. The 20th century failed to be a harbinger of peace and justice, as many had hoped. The world we know at the beginning of the 21 st century is rife with violence and injustice. Wars are being waged across the globe, violence and injustice, poverty and corruption, bad governance, are the order of the day. In many communities millions are haunted by the ghosts of the past. In South Africa in the 1990s there were high hopes for peace and reconciliation. The 1994 election was a great success. Nelson Mandela was inaugurated as the first president of the New Democratic South Africa. Mandela and Francois Pienaar together hoisted the Rugby World Cup in Ellis Park. Euphoria swept across the Rainbow Nation. We had it made!

But in recent years many of our hopes have been dashed. Change did not come as easily and as thoroughly as we had hoped. South Africa is still a deeply divided country. Prejudice, racism, violence corruption, endemic poverty, as well as injustice on many levels, bedevil our community. We need healing and reconciliation. If ever there was a time for ukubuyisa, for reconciling with the many that had died a violent death, and for ukuhlanza, for the washing of the spears, for healing in the community, it is now!

\section{Prerequisites for ReCOnciliation}

The TRC was a valiant effort in this regard. The Commission's lofty charge inspired many at the time:

To provide a historic bridge between the past of a deeply divided society characterized by strife, conflict, untold suffering and injustice, and a future founded on the recognition of human rights, democracy and peaceful co-existence for all, irrespective of colour, race, class, belief or sex.

The pursuit of national unity, the well-being of all citizens, of peace and reconciliation and the reconstruction of society. 
NGTT Deel 54, Nommers $3 \& 4$, September en Desember 2013

The recognition of the need for understanding but not for vengeance, the need for reparation but not for retaliation, for ubuntu but not for victimization. ${ }^{3}$

But did the TRC, did the South African nation at large, succeed in doing that? I personally have come to the conclusion that we are, at best, only at the beginning of things. The journey has barely started. To publish a report is one thing, to break down centuries of misunderstanding and prejudice, quite another.

Reconciliation, I have come to realise, can be attained. During the TRC years we were frequently amazed by what - by the grace of God - had taken place. But reconciliation can never be taken for granted. It can never be organised. Microwave oven reconciliation does not last. What I also realised is that a number of prerequisites for reconciliation exist, and should be studied carefully.

Allow me to page with you through the photo album of reconciliation in South Africa, looking at a number of pictures from many parts of our country, in order to understand these prerequisites for peace-building and healing.

\subsection{Reconciliation needs a clear definition}

The first picture is of a meeting of the South African TRC in Cape Town, in January 1996. Around the table, a heated discussion among the commissioners was taking place. ${ }^{4}$ Where, exactly, were we going? What was our goal? Archbishop Desmond Tutu and his colleagues were at loggerhead. How should they define "reconciliation"? At the one end of the table sat the lawyers, the jurists and the politicians who, with feet firmly planted on the ground, warned that one should not be too starry-eyed when reconciliation is on the agenda. When the dust settles in the streets, when the shooting stops, when people let go of one another's throats, be grateful, they argued. That is enough. Declare it to be reconciliation! That is, in our context, often as far as one may expect to go. Desmond Tutu as well as the clergy who serve on the TRC, at the opposite end of the table, favoured a loftier definition. When they spoke about reconciliation, they clothed it in religious terminology. Tutu opened his Bible, quoting the apostle Paul: "Therefore, if anyone is in Christ, he is a new creation; the old has passed away, behold, the new has come. All this is from God, who through Christ reconciled us to himself and gave us the ministry of reconciliation" (2 Cor 5:18, RSV).

Tutu unashamedly professed his conviction that only because God has reconciled us to Him by sacrificing his Son Jesus Christ on the cross, true and lasting reconciliation between humans became possible. The Arch kept reminding the Christian churches, all believers in all the different denominations in South Africa, of the huge responsibility we all share to become ministers of reconciliation, to act as healers in our fractured society.

In similar fashion, Tutu encouraged the spokespersons of other faith communities, Muslim, Jewish, Hindu, Buddhist, African Traditional Religion, to refer to the deepest sources of their religious traditions and beliefs, in helping to discover the true meaning of reconciliation.

From the side of African tradition, much may indeed be learned in terms of reconciliation, not only by revisiting the concepts of ukubuyisa and ukuhlanza, but especially that of ubuntu. In

3 TRC Report 1996: South African Truth and Reconciliation Commission Report (Volume 1). Cape Town: TRC, 55-57.

4 Meiring, Piet 1999: Chronicle of the South African Truth Commission. Vanderbijlpark: Carpe Diem, 129. 
NGTT: Oopbron - http://ngtt.journals.ac.za

the TRC's mandate special mention was made of the term. ${ }^{5}$ But what does ubuntu really entail? In which way does it contribute to the process of reconciliation? In the Zulu language the saying goes: Umuntu ngumuntu ngabantu (literally translated: "a person is a person through other persons").

Tutu explained the deep meaning of ubuntu as follows: ${ }^{6}$

We need other human beings for us to learn how to be human, for none of us comes fully formed into the world. We would not know how to talk, to walk, to think, to eat as human beings unless we learned how to do these things from other human beings. For us the solitary human being is a contradiction in terms.

Ubuntu is the essence of being human. It speaks of how my humanity is being caught up and bound up inextricably with yours. It says, not as Descartes did, "I think, therefore I am" but rather, "I am because I belong". I need other human beings in order to be human. The completely self-sufficient human being is subhuman. I can be me only if you are fully you. I am because we are, for we are made for togetherness, for family. We are made for complementarity. We are created for a delicate network of relationships, of interdependence with our fellow human beings, with the rest of creation. ${ }^{7}$

For Tutu it was clear: without a sense of ubuntu, reconciliation would be difficult. With it, people may reach out to one another, to embrace one another:

A person with ubuntu is open and available to others, affirming of others, does not feel threatened that others are able and good, based from a proper self-assurance that comes from knowing that he or she belongs in a greater whole and is diminished when others are. $^{8}$

In the current debate on the role of ubuntu in nation building and healing, many voices are joining in. Recently Judge Colin Lamont expanded on the definition of the word as well as on the role the concept may play in society as well as in jurisprudence in South Africa, during his ruling on the hate speech trial of Julius Malema. ${ }^{9}$

Ubuntu is recognised as being an important source of law within the context of strained or broken relationships amongst individuals or communities and as an aid for providing remedies which contribute towards more mutually acceptable remedies for the parties in such cases. Ubuntu is a concept which:

1. is to be contrasted with vengeance;

2. dictates that a high value be placed on the life of a human being;

3. is inextricably linked to the values of and which places a high premium on dignity, compassion, humaneness and respect for humanity of another;

5 TRC Report (Vol 1), 55-57).

6 Tutu, Desmond 2011: God Is Not a Christian. New York: Harper Collins, $20 \mathrm{f.}$

7 Tutu, God is Not a Christian, 22

8 Tutu, Desmond 1999: No Future Without Forgiveness. London: Rider, 7.

9 (Afri-Forum and Others vs. Malema and Others, Equity Court, Johannesburg, 2011, cf S A Legal Information Institute 23). See Google/Wikipedia link on the case. 
NGTT Deel 54, Nommers 3 \& 4, September en Desember 2013

4. dictates a shift from confrontation to mediation and conciliation;

5. dictates good attitudes and shared concern;

6. favours the re-establishment of harmony in the relationship between parties and that such harmony should restore the dignity of the plaintiff without ruining the defendant;

7. favours restorative rather than retributive justice;

8. operates in a direction favouring reconciliation rather than estrangement of disputants;

9. works towards sensitising a disputant or a defendant in litigation to the hurtful impact of his actions to the other party and towards changing such conduct rather than merely punishing the disputant;

10. promotes mutual understanding rather than punishment;

11. favours face-to-face encounters of disputants with a view to facilitating differences being resolved rather than conflict and victory for the most powerful;

12. favours civility and civilised dialogue premised on mutual tolerance.

But it is not only the African Traditional community that has a contribution to make. From the Hindu community in Kwazulu-Natal, where Mahatma Gandhi spent twenty one years of his life, much may be learned about principles and practices of satyagraha and non-violence. Addressing an International Dialogue on Religion and Reconciliation, in Holland (2002), Anthony da Silva stressed the surprising similarities among Christians and Hindus in their respective concepts of reconciliation, which may pave the way for a real dialogue and cooperation. While the very term reconciliation has a strong Western Christian religio-cultural rootedness, the Gandhian concepts of satyagraha and ahimsa refer to something remarkably akin. Da Silva pointed to four areas of convergence of Christian and Hindu views which may facilitate the Hindu-Christian dialogue: ${ }^{10}$

1. Nonviolence (ahimsa) and reconciliation are deeply rooted in God. They derive their dynamism and transforming power in the belief that the love of God demands that we repair broken human relationships, that we forgive or adhere to ahimsa.

2. Gandhi's satyagraha (truth force) is an Eastern articulation of reconciliation. "Truth force" sustains and drives nonviolent behaviours, which are expressions of forgiveness and reaching out to the other. Nonviolence is implied in forgiveness, since we cannot be violent and promote reconciliation at the same time.

3. Reconciliation through nonviolence has much in common with the four dimensions of forgiveness, namely, moral judgment, forbearance, empathy, and repairing of broken relationships.

4. Finally, the assumption of human interdependence that underlies ahimsa is also an important part of the reconciliation process that seeks to bring together the perpetrator, the victim, and the community through restorative justice.

10 Da Silva 2002: Da Silva, Anthony 2002: Through Non-Violence to Truth: Gandhi's Vision of Reconciliation, in Helmick, Raymond (et al.) 2002: Forgiveness and Reconciliation Philadelphia/London: Templeton Foundation Press, 279. 
NGTT: Oopbron - http://ngtt.journals.ac.za

The South African Muslim community has a role to play, as well. The different approaches to reconciliation between Christians and Muslims are often discussed: Christians opting for, in the eyes of many Muslims, a far too'easy' approach. Christians tend to stress forgiveness and grace, while their Muslim counterparts call for justice and reparation before reconciliation may be considered. Addressing the TRC's special Faith Communities' Hearing (November 1996) Faried Essack however called upon Christians and Muslims, the leadership as well as the laity, to make every effort to reach out to one another, to enter into dialogue, to try and understand each other, to respect our different traditions and to allow one another our heartfelt convictions.

It will not be easy, one has to add. We come from a history where we often misunderstood one another, discriminated against one another, lived with caricatures of one another, marginalised one another, even blatantly opposed the other. The fact that both Islam and Christianity are missionary religions, claiming the divine command to spread their message to all people, can lead - and sometimes does lead - to confrontation. As Christians we may never excuse ourselves from the obligation to share our faith in Jesus Christ with all people, also with our Muslim neighbours in South Africa. But it must be done in a spirit of respect and love as well as with a willingness to listen to the other and to work together, wherever and whenever possible. It behoves us to take Essack's admonition seriously: ${ }^{11}$

Our challenge is thus to remind the others persistently of our presence and of the value of the religious heritage which we bring with us, but to do so in a manner that they would want to embrace us as partners in the reconstruction and reconciliation of our nation.

For future relationships in the country to be healthy, it is of extreme importance to take cognizance of the issues raised by die Muslim spokespersons at the TRC hearing. Christians and Muslims share South Africa with one another, as well as with adherents to the other religions. We have a common loyalty to our communities and to one another. South Africa, still trying to find its way on the new road of democracy and nation building, needs the goodwill and the effort of all its citizens in this regard.

In the final Report of the Truth and Reconciliation high hopes were expressed of the contribution that the different faith communities will be able to make in terms of establishing the truth and, especially, in terms of reconciliation. Numerous challenges were made, inter alia: ${ }^{12}$

1. for the different religious communities to seek ways to communicate with one another as a basis for eliminating religious conflict and promoting inter-religious understanding;

2. to seek ways to incorporate marginalized groups into their communities;

3. to promote a culture of tolerance and peaceful co-existence;

4. to inspire their members to work together in a peace corps to help communities in need;

5. to organise reconciliation ceremonies, creating liturgies to heal and to celebrate the

6. reconciliation that we do experience in the country;

11 Esack, Faried 2002: An Islamic View of Conflict and Reconciliation in the South African Situation, in Jerald D Gort (et al): Religion, Conflict and Reconciliation. Amsterdam-New York: Rodopi, 315f.

12 TRC Report (Vol 5), pp 316ff. 
NGTT Deel 54, Nommers $3 \& 4$, September en Desember 2013

7. and, finally, to develop theologies designed to promote reconciliation and a true sense of community in the nation.

Is it possible that South Africans, coming from a history of prejudice and division and discrimination, may indeed provide the world with an alternative experience in inter-religious relationships? The South African process of Truth and Reconciliation was far from perfect, but it did provide some useful pointers that may inform the dialogue between Muslims, Hindus, African Traditionalists and Christians in years to come.

\subsection{Reconciliation and truth go hand in hand}

Central to the business of reconciliation and peace-making, is the quest for truth. The South African TRC, therefore, was mandated "to establish the truth in relation to past events as well as the motives for and circumstances in which gross violations of human rights have occurred, and to make the findings known in order to prevent repetition of such acts in future".13 When the Minister of Justice Dullah Omar introduced the TRC legislation to Parliament he exhorted all South Africans "to join in the search for truth without which there can be no genuine reconciliation".14 When political change came to South Africa, the issue and the wisdom of truth finding was widely debated. There were those who, with the best intentions, said: "Let us close the books, let us forgive and forget!" The response of many - Archbishop Tutu included - was: "No! We can never do that! We need to open the books, we need to deal with our past - horrible as it may be - before we close the books". "We have to face the past", Archbishop Desmond Tutu was fond of saying, "because if you don't face the past, it may return". Searching for truth can be painful and difficult, even hazardous. It can disrupt the journey towards reconciliation. But in the long run, it is the only way to go. Reconciliation is about uncovering the truth, not about amnesia. ${ }^{15}$

But the quest for truth is more than collecting facts and weighing findings. It has a deeper side to it. In the traditions of all religions, searching for the truth turns into a spiritual exercise. Finding truth goes far beyond establishing historical and legal facts. It has to do with understanding, accepting accountability, justice, restoring and maintaining the fragile relationship between human beings - as well as the quest to find the Ultimate Truth, God Himself. The search for truth needs to be handled with the greatest sensitivity. If that is not the case the nation may bleed to death. But if we succeed it may pave the way to a national catharsis, to peace and reconciliation, to the point where the truth in all reality sets one free.

This, indeed, is what happened during the Truth and Reconciliation Commission years. Many victims of gross human rights violations, 22400 in total, approached the TRC. For many telling their stories and reliving the agonies of the past, was difficult. Emotions sometimes ran high and tears flowed freely, but in the vast majority of cases, testifying before the Commission proved to be a cathartic and a healing experience. The victims were edified and honoured by the process. At a hearing in Soweto an elderly gentlemen remarked: "When I was tortured at John Vorster Square my tormentor sneered at me: 'You can shout your lungs out. Nobody will ever hear you!' Now, after all these years, people are hearing me!"16 Many perpetrators

\section{TRC Report 1:55}

14 Van Vught, William and Cloete, Daan 2000: Race and reconciliation in South Africa. Lanham: Lexington Books, 190

15 Meiring, Chronicle, 128

16 Van Vught, Cloete, Reconciliation, 190. 
NGTT: Oopbron - http://ngtt.journals.ac.za

who appeared before the TRC had a similar experience. When they, after much anguish and embarrassment, unburdened themselves to the Amnesty Committee and when they made a full submission of all the relevant facts of their misdeeds - after the questioning and crossquestioning came to an end - it was as if a cloud lifted.

But it was not only the victims and the perpetrators that needed the truth-telling, the nation needed it as well - to listen to the truth, to be confronted by the truth, to be shamed by the truth, to struggle with the truth and finally to be liberated by the truth. The South African TRC was a public process. All the hearings were open to the nation and large audiences attended the events. The media had free access to all sessions of the Commission. Every day the newspapers carried TRC reports. Every night, after the eight o'clock news in a special TRC programme, the highlights of the day were shown. The nation had to know! The majority of South Africans entered into the spirit of the Truth and Reconciliation process. They wanted to come to grips with the past. Sadly, there were also those who did not want to know. Up till the end of the process, the TRC was dogged by some - especially from the white community who were unwilling or unable to accept the truth and who described the TRC's work as a onesided witch-hunt, designed to shame and embarrass one section of the community.

The process however, was not intended to stop when the TRC closed its doors. Truth telling had to go on. There are still millions of South Africans from all the communities in the land, who did not qualify to appear before the TRC but who also are in need of healing, who also need to be recognized and edified by having people listen to their stories. They need people to share their pain. In its Final Report the TRC urged the South African faith communities to continue with this process, to invite members of all walks of life - Black and White, perpetrators and victims alike - to meet one another and to talk to each other. The expectation was that the churches would host a large number of "mini TRCs", enabling hundreds of thousands of South Africans to start to talk - and to listen - to one another.

The need is still there, maybe even greater than before, for the faith communities to bring people together from the different parts of our fractured society to meet one another and to share with one another. Ellen Kuzwayo, a celebrated South African author wrote: ${ }^{17}$

Africa is a place of storytelling. We need more stories, never mind how painful the exercise may be. This is how we will learn to love one another. Stories help us to understand, to forgive and to see things through someone else's eyes.

\subsection{Reconciliation and justice are two sides of a coin}

Justice and reconciliation are two sides of the same coin. For reconciliation to happen, there has to be a sense of justice being part and parcel of the process. Lasting reconciliation can only flourish in a society where justice is seen to be done. In South Africa this brings a number of issues to the fore: not only the issue of proper government reparation to the victims of human rights abuses to balance the generous granting of amnesty to perpetrators of the abuses, but also the wider issues involving every South African: unemployment, poverty, affirmative action, equal education, restitution, the redistribution of land, reparation tax, et cetera.

Justice, the pictures in our book tell us, has many faces that speak with many voices. Listen to some of them. Archbishop Tutu often made an important distinction between retributive

17 Quoted from Van Vught, Cloete, Reconciliation, 196. 
NGTT Deel 54, Nommers $3 \& 4$, September en Desember 2013

justice and restorative justice. Retributive justice, he said, has as raison d'être the need to punish the perpetrator. But there is another kind of justice, restorative justice, whose chief purpose is not punitive but restorative, healing; $;^{18}$

It holds as central the essential humanity of the perpetrator of even the most gruesome atrocity, never giving up on anyone, believing in the essential goodness of all as created in the image of God, and believing that even the worst of us still remains a child of God with the potential to become better, someone to be salvaged, to be rehabilitated, not to be ostracised but ultimately to be reintegrated into the community. Restorative justice believes that an offence has caused a breach, has disturbed the social equilibrium, which must be restored, and the breach healed, in a process through which the offender and the victim can be reconciled and peace restored.

Tutu's plea for restorative justice was, however, not always accepted. Tutu himself vividly describes in his book No Future Without Forgiveness his experience when he, after visiting some of the horrendous genocide sites where almost a million Rwandese died at the hands of their compatriots (February-April 1994), was invited to address a rally in the Kigali stadium. He made a passionate plea for forgiveness and reconciliation, in spite of everything that happened in the past, arguing that without that there is no future for Rwanda and its people. Neither his audience nor the Rwandese government, were persuaded. Forgiveness, blanket amnesty in a society where there was for years no rule of law, no sense of justice, was impossible, they maintained. They liked the South African TRC process, especially the opportunity given to thousands of victims to tell their stories, but blanket amnesty to perpetrators, guilty of heinous deeds, was unacceptable. Tutu's plea that they needed to move from retributive justice to restorative justice, fell on deaf ears: ${ }^{19}$

The president of Rwanda responded to my sermon with considerable magnanimity. They were ready to forgive, he said, but even Jesus had declared that the devil could not be forgiven. I do not know where he found the basis for what he said, but he was expressing a view that found some resonance (among his people): that there were atrocities that were unforgivable.

Another aspect of justice was highlighted by Thabo Mbeki in his address to Parliament in May 1998. In his capacity as Deputy President of South Africa, he was invited to speak at the opening of Parliament in May 1998. In a speech that was widely reported in the media, he stressed the vital link between reconciliation and justice. To his way of thinking it was especially economic justice that was at stake. His definition of reconciliation was clear cut: the creation of a nonracial, non-sexist society, the healing of the divisions of the past, and the improvement of the quality of life of all citizens. To reach this, first and foremost, the issue of economic justice needs to be addressed: ${ }^{20}$

South Africa is a country of two nations. One of the nations is white and well off, and because of their background and their economic, physical, and educational

18 Tutu: God Is Not a Christian, $42 \mathrm{f}$

19 Tutu, No Future Without Forgiveness, 209

20 Boraine, Alex 2001: A country unmasked. Oxford: Oxford University Press, 349 
NGTT: Oopbron - http://ngtt.journals.ac.za

infrastructures, they are able to exercise their right to equal opportunity and the development opportunities that flow from the new Constitution. The second and larger nation of South Africa, is black and poor with the worst being affected women in rural areas, the black population in general, and the disabled. This nation lives under conditions of grossly underdeveloped economic, physical, educational, communication and other infrastructures.

Alex Boraine, deputy chairperson of the TRC, voiced yet another concern. The quest for reconciliation may in itself become an instrument of oppression. He often stressed that reconciliation must never be sought at the expense of social action, that it never should be used as an excuse for harbouring injustice. He liked to quote the Filipino poet J. Cabazares to make his point: ${ }^{21}$

Talk to us about reconciliation

Only if you first experience

The anger of our dying.

Talk to us about reconciliation

If your living is not the cause of our dying.

Talk to us about reconciliation

Only if your words are not products of your devious scheme

To silence our struggle for freedom.

Talk to us about reconciliation

Only if your intention is not to enrich yourself

More on your throne.

Talk to us about reconciliation

Only if you cease to appropriate all the symbols

And meanings of our struggle.

To really stand for justice may be difficult, even hazardous. But is a price that needs to be paid. One has to identify with the victim, in order to be of service. A very poignant picture in our gallery is of Beyers Naudé, the Dutch Reformed Church minister who left his Afrikaans congregation to join in the struggle against apartheid, who was standing trial in Johannesburg. The defence advocate questioned him on his understanding of the concept of reconciliation. Beyers Naudé who was banned for his commitment to the anti-apartheid struggle faced the judge:22

No reconciliation is possible without justice, and whoever works for reconciliation must first determine the causes of injustice in the hearts and lives of those, of either the persons or groups, who feel themselves aggrieved. In order to determine the causes of the injustice a person must not only have the outward individual facts of the matter, but as a Christian you are called to identify yourself in heart and soul, to live in, to think in, and to feel in the heart, in the consciousness, the feelings of the person or the persons who feel themselves aggrieved. This is the grace that the new birth in Jesus Christ gives a person - every person who wishes to receive it.

Here, again, is a huge challenge to every denomination in the country, not only by standing for

21 Boraine, A Country Unmasked, 361.

22 De Gruchy, John 1968. Cry Justice! London: Collins, 171. 
NGTT Deel 54, Nommers $3 \& 4$, September en Desember 2013

justice and to make its prophetic voice against all forms of injustice heard in South Africa, but by getting its own house in order. The Confession of Belhar, on this point, calls all the churches to seriously reflect on their calling in this regard. ${ }^{23}$

We believe that God has revealed himself as the one who wishes to bring about justice and true peace among men; that in a world full of injustice and enmity he is in a special way the God of the destitute, the poor and the wronged and that he calls his church to follow him in this; that he brings justice to the oppressed and gives bread to the hungry; that he frees the prisoner and restores sight to the blind; that he supports the downtrodden, protects the stranger, helps orphans and widows and blocks the path of the ungodly; that for him pure and undefiled religion is to visit the orphans and the widows in their suffering; that he wishes to teach his people to do what is good and to seek the right;

that the church must therefore stand by people in any form of suffering and need, which implies, among other things, that the church must witness against and strive against any form of injustice, so that justice may roll down like waters, and righteousness like an everflowing stream; that the church as the possession of God must stand where he stands, namely against injustice and with the wronged; that in following Christ the church must witness against all the powerful and privileged who selfishly seek their own interests and thus control and harm others.

\subsection{Reconciliation needs an honest confession as well as a willingness to forgive}

Reconciliation, the washing of the spears, our picture gallery tells us, requires a deep, honest confession - and a willingness to forgive. The TRC Act did not require of perpetrators to make an open confession of their crimes, to publicly ask for forgiveness before amnesty was granted. Yet it has to be stated clearly that lasting reconciliation rests firmly upon the capacity of perpetrators, individuals as well as perpetrator communities, to honestly, deeply, recognize and confess their guilt towards God and their fellow human beings, towards individual victims as well as victim communities - and to humbly ask for forgiveness. And it equally rests upon the magnanimity and grace of the victims to reach out to them, to extend forgiveness.

A prime example of the latter, was Nelson Mandela who after suffering so much at the hands of the apartheid regime, returned from twenty seven years in captivity with one goal in mind to liberate all South Africans, white and black alike. Let me remind you of the picture of Madiba walking through the prison gates. His words reverberated across the globe: ${ }^{24}$

It was during those long and lonely years that my hunger for the freedom of my own people became a hunger for the freedom of all people, white and black. I knew as well as I knew anything that the oppressor must be liberated just as surely as the oppressed. A man who takes away another man's freedom is a prisoner of hatred, he is locked behind the bars of prejudice and narrow-mindedness. I am not truly free if I take away someone else's freedom, just as surely I am not free when my freedom is taken away from me. The oppressed and the oppressor alike are robbed of their humanity. When I walked out of prison that was my mission, to liberate the oppressed and the oppressor.

23 Uniting Reformed Church: The Confesson of Belhar, Article 4.

24 Mandela, Nelson 1994: Long walk to freedom. London: Macdonald Purnell, 617. 
NGTT: Oopbron - http://ngtt.journals.ac.za

Tutu who has become the symbol of reconciliation in South Africa, has written movingly on the issue of forgiveness. In his No Future Without Forgiveness he, against the backdrop of his Truth and Reconciliation Commission experience, reflected on the many aspects of forgiveness. Forgiveness is a risky business, Tutu explains. When one embarks on the business of asking for and giving forgiveness, you are making yourself vulnerable. Both parties may be spurned. The process may be derailed by the inability of victims to forgive, or by the insensitivity or arrogance of the perpetrators who do not want to be forgiven. But remember, the archbishop counsels, forgiveness and reconciliation are meant to be a risky and very costly exercise. Quoting the ultimate example of Jesus Christ, he writes: "True reconciliation is not cheap. It cost God the death of his only begotten Son."25

Tutu further discusses the misunderstanding that reconciliation asks for the glossing over of past mistakes and injustices, that reconciliation requires national amnesia. This is totally wrong: Forgiving and being reconciled are not about pretending that things are other than they are. It is not patting one another on the back and turning a blind eye to the wrong. True reconciliation exposes the awfulness, the abuse, the pain, the degradation, the truth. It could even sometimes make things worse. It is a risky undertaking, but in the end it is worth wile, because in the end there will be real healing from having dealt with a real situation. Spurious reconciliation can bring only spurious healing.

Forgiveness, however, means abandoning your right to retribution, your right to pay back the perpetrator in his own coin. But is a loss, Tutu maintains, which liberates the victim. ${ }^{26} \mathrm{~A}$ recent issue of the journal Spirituality and Health had on its front cover a picture of three US ex-servicemen standing in front of the Vietnam Memorial in Washington DC. One asks: "Have you forgiven those who held you prisoner of war?" "I will never forgive them," replies the other. His mate says: "Then it seems they still have you in prison, don't they?"

One of the most poignant pictures of healing and forgiveness, took place in $\mathrm{KZN}$, when the former police officer Brian Mitchell who had been sent to prison for the massacre of Trust Feeds, asked the TRC to mediate between him and the families of the victims that were killed by his hand. Eight years earlier Mitchell, with two fellow policemen, attacked a house under the impression that a group of United Democratic Front officials, closely connected to the ANC, were meeting. They were wrong. The house was filled with men and women and children attending a vigil, the night before a funeral. When the policemen left eleven were killed, and a many more were wounded. At a meeting called together by the TRC Brian Mitchell humbly asked for forgiveness, committing himself to the community, to give something back to the bereaved. Jabulisiswe Ngubane who had lost both her mother and her children in the attack, told a journalist: "It was not easy to forgive, but because he stepped forward to ask for forgiveness, I have no choice. I must forgive him". ${ }^{27}$

Some years later President Jacob Zuma, referred to the incident:

We must therefore commend Brian Mitchell, the former police captain for coming clean before the TRC Amnesty Committee, with regard to his role in this massacre. That courageous step has enabled this community to come to terms with their suffering and extend their forgiveness. The role Mr Mitchell is playing in the rebuilding of the

25 Tutu, No Future Without Forgiveness, 218.

26 Tutu, No Future Without Forgiveness, 218.

27 Meiring, Chronicle, 123. 
NGTT Deel 54, Nommers 3\& 4, September en Desember 2013

community as well makes the story of Trust Feed incredibly unique. Only in South Africa can someone who caused so much pain, be openly accepted back into the community. ${ }^{28}$

If individuals need to ask for forgiveness, and are called upon to grant forgiveness, the same goes for communities. And it especially goes for the leaders of these communities. Professor Willie Jonker, at the Rustenburg Conference (1986), made an eloquent plea for forgiveness to his black fellow Christians on behalf of Afrikaners, especially those belonging to the Dutch Reformed Church, for the atrocities of apartheid. Some years later (1994) the General Synod of the DRC followed Jonker's statement with a public apology for the sin and heresy of apartheid, asking forgiveness from fellow South Africans for the pain and the agony caused by their support of apartheid. The DRC had its own spears to wash.

\subsection{Reconciliation requires a firm commitment}

Reconciliation, history teaches us, is not for the fainthearted. To act as a reconciler, a builder of bridges between opposing individuals as well as between communities, asks for a strong commitment, resilience, and nerves of steel. It is often a hard and thankless task. But, bridges are made to be trodden upon! Jesus Christ, the ultimate Reconciler put his life on line - and He expected of his disciples to follow his example. During the 1930s and 1940s the German theologian Dietrich Bonhoeffer repeatedly warned his fellow-Christians against the temptation of 'cheap grace', which is a mortal enemy to the gospel. 'Costly grace' should be the aim of all believers who, knowing and accepting their salvation as a free gift from God, offer themselves to Him, and to one another, as a living sacrifice. In our times and in our context, it seems to me, we are called to warn against a similar temptation, that of 'cheap reconciliation', reconciliation without cost, which too is a mortal enemy to the gospel of our Lord. We need to rediscover on a daily basis what 'costly reconciliation' entails, and dare to live according to our discovery. ${ }^{29}$

Another picture in our gallery is that of Bishop Mvume Dandala, best known for his outstanding work as a peacemaker during the years before the 1994 elections, when political violence on the East Rand between hostel dwellers who aligned themselves with the Inkhatha Freedom Party (IFP) and people living in the neighbouring township who favoured the ANC, was particularly intense. As a senior minister of the Central Methodist church in Johannesburg, he brokered more than 30 peace agreements in Johannesburg's inner city and in East Rand hostels. "He would actually go where angels and devils feared to tread," says Ishmael Mkhabela, executive director of the Interfaith Community Development Association (ICDA). For Gertrude Mzizi, currently an IFP MP in the Gauteng provincial legislature, Dandala was the only cleric accepted in the hostels: ${ }^{30}$

The South African Council of Churches (SACC) was regarded as a wing of the ANC. All members of the IFP were rejecting people aligned to the SACC because it was aligned to the ANC. He is the only one who ever came to us. He never feared us. He never asked for a police escort. He just came to us because we were human beings and he acknowledged our suffering and he was interested in peace. All the peace we have in Thokoza, Katlehong and Vosloorus is mainly attributable to him.

28 Wikipedia: link on Brian Mitchell, Trust Feed.

29 Bonhoeffer, Dietrich 1960. The Cost of Discipleship. New York: Macmillan.

30 Wikipedia: link on Bishop Mvume Dandala. 


\section{THE GOD OF SURPRISES}

In South Africa, God was good to South Africa, providing us not only with leaders like Nelson Mandela, Desmond Tutu, Beyers Naudé and Mvume Dandala, but tens of thousands of women and men, some young, some old, who were willing to rise to the occasion. In many instances they had to pay a very costly price for being harbingers of peace, many of them, ordinary citizens who reached beyond themselves, to facilitate reconciliation in their communities. "It never ceases to astonish me", Tutu wrote in between Truth Commission hearings, "the magnanimity of many victims who suffered the most heinous violations, who reach out to embrace their tormentors with joy, willing to forgive and wanting to reconcile.". ${ }^{31}$

Allow me to show a very personal last picture, a final reminder that ukubuyisha (reconciling with the dead) and ukuhlanza, the washing of the spears (reconciling with the living) do happen, taken from my own Chronicle of the Truth Commission: ${ }^{32}$

"One can see God's influence in what is happening tonight", Mcibisi Xundu, pastor and TRC committee member said, looking at Eric Taylor, former security police officer who had applied for amnesty for his part in the killing of the 'Cradock Four.' "It is God who has led you to take this step towards reconciliation".

A few weeks earlier a young DRC pastor Charl Coetzee approached me with a request. One of his parishioners, Eric Taylor, wanted to meet the family of Matthew Goniwe, the activist he had tortured and murdered. Mrs Goniwe, a strong critic of the TRC process, refused to come, but the rest of the family as well as the families of the rest of the Cradock Four travelled from Cradock to Port Elizabeth for the occasion. Suspicion and anger were in the air. The families of the victims had many questions, needed many answers. Taylor answered as best he could. At the end of a long evening he turned to the Goniwe family and to their colleagues: "I came to ask you to forgive me, if the Lord can give you the strength to do that".

The response was moving. One after another the family members came to the fore to shake Eric Taylor's hand and to assure him of their forgiveness. Many a cheek were wet with tears. The son of Goniwe walked up to the policeman. His right arm was in plaster, but with his left arm he embraced Eric Taylor. "It is true", he said, "you murdered my father. But we forgive you..."

When Charl Coetzee reported to me about the meeting, I immediately phoned Desmond Tutu in Cape Town. "I have heard the news", he commented. "Mrs Goniwe told me this morning that the next time she would be there!" When we concluded our conversation Tutu wanted us to pray: "O Lord, we thank You for being the God of surprises, for surprising us every day, for the miracles of reconciliation in our country..."

These, then, are some of the pictures of reconciliation from the South African book, the stories of ukubuyisa and ukuhlanza in South Africa. But many more images and stories of healing and forgiveness, are needed. In South Africa, eighteen years after the new democratic dispensation came into being, we are still struggling with seemingly insurmountable problems. In 1994, as noted above, we harboured high hopes for the Rainbow Nation, that reconciliation and peace-

31 Meiring, Piet 2002: Unshackling the ghosts of the past, in Missionalia 30:1 (April 2002), 68.

32 Meiring, Chronicle, 123f. 
NGTT Deel 54, Nommers $3 \& 4$, September en Desember 2013

building, the eradication of poverty and injustice, development ensuring a better life for all, would be the order of the day. But for many, the colours of the rainbow have paled. Hunger, poverty, inequality, moral decay, corruption, political instability, labour unrest, poor service provision, human rights abuses, racism, xenophobia, HIV-Aids, continue to ravage our people. The Christian Churches and the other faith communities dare not stand apart. They bear a huge responsibility to become involved, to help rectify the situation, indicating an alternative way, to help turning swords into ploughshares.

But we may take heart. Circumstances can change. People can make a difference. Even the direst of circumstances may change. After presiding over many hearings where South African victims and perpetrators tabled their stories of cruelty and suffering, after helping prepare a report on a country torn apart by racism and prejudice - but also taking note of the role that many have played to bring peace, to foster reconciliation - the chairperson of the TRC could not but rejoice. His words serve as an exhortation to all. This, indeed, is what ukubuyisha and ukuhlanza is about: ${ }^{33}$

We have been wounded but we are being healed. It is possible even with our past suffering, anguish, alienation and violence to become one people, reconciled, healed, caring, compassionate and ready to share as we put our past behind us to stride into the glorious future God holds before us as the Rainbow People of God.

\section{BIBLIOGRAPHY}

Bonhoeffer, Dietrich 1960: The Cost of Discipleship. New York: Macmillan Da Silva, Anthony 2002: Through Non-Violence to Truth: Gandhi's Vision of Reconciliation, in Helmick, Raymond (et al, eds) 2002: Forgiveness and Reconciliation: Philadelphia/London: Templeton Foundation Press.

De Gruchy, John 1968: Cry Justice! London: Collins

Esack, Faried 2002: An Islamic View of Conflict and Reconciliation in the South African Situation, in Jerald D Gort (et al): Religion, Conflict and Reconciliation. Amsterdam-New York: Rodopi.

Meiring, Piet 1999: A Chronicle of the Truth Commission. Vanderbijlpark: Carpe Diem 2002: Unshackling the ghosts of the past, in Missionalia 30:1 (April 2002), 68.

South African Truth and Reconciliation Commission 1998: TRC Report, Volumes 1-7. Cape Town: TRC

Tutu, Desmond 1999: No future without forgiveness. London: Rider 2011: God is Not a Christian. New York: Harper Collins

Uniting Reformed Church in Southern Africa 2008: Confession of Belhar. Cape Town: URCSA

Villa-Vicencio C and Verwoerd, W (eds) 2000: Looking back, reaching forward. Reflections on the TRC in South Africa. Cape Town: UCT Press

Wikipedia: Links on Bishop the Malema Court Case, Mvume Dandala, and on Brian Mitchell/Trust Feeds.

33 Meiring, Chronicle: 379. 